\title{
Vem ska sköta hemarbetet? Hushållstjänsternas betydelse för upprätthållandet av mellanskiktens livsmönster och könsarbetsdelning
}

\author{
Ellinor Platzer
}

SAMMANDRAG: I sin avhandling Från folkhem till karriärhushåll från 2007 ger Ellinor Platzer en översikt över hur kvinnor under olika tidsperioder har förenat förvärvsarbete med hushållsarbete och familjeliv. I den här artikeln (kapitel 4 i boken) redovisar Platzer en studie från början av 2000-talet där hon tittar närmare på vad som kännetecknar de familjer som köper hushållstjänster, hur de beskriver sina erfarenheter och hur de ser på de anställda. Särskilt fokus ligger på relationen mellan hushållstjänster och jämställdhet: Platzer analyserar hur jämställdhetsidealen och könsarbetsdelningen ser ut i familjerna och vad köpet av hushållstjänster får för betydelse för jämställdheten. Fram träder en tydlig bild av vad familjerna anser vara "lämplig arbetskraft" och hur det hänger samman med hushållsarbetarens etniska tillhörighet. Det visar sig också att behovet av kontroll över det utförda arbetet för många uppväger de risker som finns med informella och "svarta" arrangemang.

NYCKELORD: jämställdhet; könsarbetsdelning; hushållsarbete; hushållsnära tjänster; städhjälp; au pair; etnicitet; svartarbete.

pUbliceringshistorik: Utdrag (kapitel 4) ur Ellinor Platzers avhandling Frän folkhem till karriärhushåll. Den nya husliga arbetsdelningen, Arkiv förlag 2007.

ELLINOR PLATZER är doktor i sociologi vid Linnéuniversitetet.

FÖRSLAG PÅ KÄLLANGIVELSE:

Platzer, Ellinor (20I3) "Vem ska sköta hemarbetet? Hushållstjänsternas betydelse för upprätthållandet av mellanskiktens livsmönster och könsarbetsdelning", i Arkiv. Tidskrift för sambällsanalys, nr I, s. 37-59.

DOI: http://dx.doi.org/IO.I3068/2000-62I7.I.2

(C) Ellinor Platzer/Arkiv förlag \& tidskrift 2013 (publicerad I3 december 20I3)

Artikeln distribueras enligt en upphovsrättslicens från Creative Commons:

Erkännande-Ickekommersiell-IngaBearbetningar 3.0 Unported, som medger fri ickekommersiell användning och spridning i oförändrat skick så länge källan anges. 
Arkiv. Tidskrift för samhällsanalys är en sakkunniggranskad vetenskaplig tidskrift för samhällsvetenskap och historia. Samtliga artiklar publiceras fritt tillgängliga på:

www.tidskriftenarkiv.se

(beständig länk, DoI: http://dx.doi.org/IO.I3068/2000-62I7)

Den här artikeln finns tillgänglig i följande format:

PDF \& HTML: via beständig länk, DOI: http://dx.doi.org/IO.I3068/2000-62I7.I.2 EPUB: ingår i e-boksutgåva av numret, ISBN: 978 9I 79242503

TRYCK: ingår i bokutgåva av numret, ISBN: 978 9I 7924 25I O

Grafisk utformning och sidnumrering är identisk i pdf och tryck.

Samtliga artiklar i nr I (2013) nås via beständig länk, DOI: http://dx.doi.org/I0.13068/2000-6217.I

Arkiv. Tidskrift för sambällsanalys ISSN: 2000-62I7 (för elektronisk resurs)

ISSN: 2000-6225 (för tryckta nummer)

ges ut av

Stiftelsen Arkiv för främjande och spridning av samhällsvetenskaplig och historisk forskning

genom

Arkiv förlag \& tidskrift

Box 1559

SE-22I OI Lund

BESÖK: L Gråbrödersg 3 c, ipg

TEL: O46-I3 3920

ARKIV FÖRLAG: arkiv@arkiv.nu·www.arkiv.nu

TIDSKRIFTEN ARKIV: red@tidskriftenarkiv.se · www.tidskriftenarkiv.se

ANSVARIg UTGIVARE \& CHEFREDAKTÖR: Sven Hort

ADMINistrativ RedAKTÖr: David Lindberg

RedAKtörer: Paavo Bergman, Lisa Kings, Zhanna Kravchenko 


\title{
Vem ska sköta hemarbetet? Hushållstjänsternas betydelse för upprätthållandet av mellanskiktens livsmönster och könsarbetsdelning
}

\author{
ELLINOR PLATZER
}

Sedan mitten av 1980-talet har hushållstjänsternas omfattning i Sverige ökat dramatiskt. Gemensamt för de flesta som köper hushållstjänster är att de ägnar mycket tid och kraft åt sitt arbete. Med få undantag är de högavlönade.

Det övergripande syftet med den här studien är att undersöka vad som kännetecknar familjer som köper hushållstjänster, hur de beskriver sina erfarenheter och hur de ser på de anställda. Jag har också intresserat mig för relationen mellan hushållstjänster och jämställdhet och därför fokuserat på respondenternas jämställdhetsideal, hur könsarbetsdelningen i hemmet ser ut i praktiken och vilken betydelse hushållstjänsterna verkar ha för jämställdheten i det egna parförhållandet.

\section{Materialinsamling}

Jag samlade in mitt material vintern 200I-02. Bland annat intervjuade jag tolv personer, fem kvinnor och sju män, som har husligt anställda. Hälften har au pair och den andra hälften några timmars städhjälp i veckan; tre respondenter har båda delarna men räknas här till den förra gruppen. Den senare gruppen intervjuade jag personligen och den förra per telefon,

Artikeln är ett utdrag (kapitel 4) ur Ellinor Platzers avhandling Från folkhem till karriärhushåll. Den nya husliga arbetsdelningen, Arkiv förlag 2007. 
av skäl som jag inte kunde påverka. Jag intervjuade en kontrollgrupp: tre kvinnor (personligen) och en man (per telefon) som inte köper hushållstjänster. De är i åldrarna 36-52 år, alla lever tillsammans med en partner och tre av dem har hemmaboende barn. Alla utbildningsnivåer finns representerade och hushållens samlade inkomst är medelhög eller hög. Det är en socialt heterogen grupp som alltså har det gemensamt att de inte köper hushållstjänster. Materialet är litet och därför av begränsat empiriskt värde, men som kontrast till gruppen som köper hushållstjänster har det varit användbart.

Som ett komplement till intervjuerna skickade jag ut enkäter till 80 hushåll i en större svensk stad som köpte städhjälp genom sin hyresvärd. Svarsfrekvensen blev knappt 40 procent, varför resultatet inte har något statistiskt värde, men jag använder ändå materialet i viss omfattning. Det var 29 personer (2I kvinnor och 8 män) som besvarade enkäten. De är mellan 22 och 79 år gamla, de flesta är 5I-60. Flertalet respondenter upp till 50 år har hemmavarande barn. Det ingår nio pensionärer, ${ }^{\mathrm{I}} \mathrm{i}$ huvudsak låginkomsttagare. Fyra pensionärer är högutbildade och resten har en medelhög utbildningsnivå. När man räknar bort pensionärerna har tretton av de övriga hushållen hög inkomst, sex medelhög inkomst och ett - en undersköterska mellan 22 och 30 år som är sambo och har barn - låg inkomst. Om yrkestillhörighet vägs samman med utbildningsnivå och hushållets samlade inkomst är det bara undersköterskan som kan anses representera arbetarklassen.

\section{Arbetsgivarna}

Alla respondenter utom en lever ihop med en partner och samtliga intervjuade och deras partner arbetar heltid. Alla utom en har minst ett barn boende i hemmet. Hälften har universitetsexamen, hälften har genomfört yrkesutbildningar, ibland kompletterade med universitetskurser. Hushållets samlade inkomst är med endast ett undantag hög. Nedan följer en beskrivning av intervjupersonerna under fingerade namn:

I. Mycket tyder på att pensionärer utgör en stor grupp bland dem som köper hushållstjänster. Det beror sannolikt på att den kommunala hemtjänsten erbjuder väldigt få timmar och tar ut höga avgifter av ekonomiskt starka pensionärer. 
Anki Alveteg, 45 år, journalist, gift, två barn varav ett bor hemma, städhjälp en gång i veckan

Bodil Bengtsson, 49 år, specialpedagog, gift, två barn som bor hemma, städhjälp en gång i veckan

Christina Castor, 5I år, purser, gift, två barn som bor hemma, städhjälp en gång varannan vecka

Didrik Davén, 76 år, egen företagare, gift, två barn som bor hemma, en anställd boende i hushållet

Eugen Eriksson, 36 år, chef på mellanstort företag, gift, tre barn som bor hemma, en anställd boende i hushållet

Filip Franzén, 43 år, pilot, ensamstående, två barn som bor hemma, en anställd boende i hushållet

Georg Göös, 53 år, egensysselsatt konsult, gift, tre barn varav två bor hemma, städhjälp en gång i veckan

Harriet Hagberg, 30 år, egensysselsatt jurist, sambo, inga barn, städhjälp en gång i veckan

Iris Isaksson, 4I år, i ledningen för stort företag, gift, två barn som bor hemma, en anställd boende i hushållet

Janos Jacobi, 5I år, företagsledare, gift, två barn varav ett bor hemma, städhjälp en gång i veckan.

Klas Kårberg, 44 år, läkare, gift, fyra barn som bor hemma, en anställd boende i hushållet

Linus Lindén, 44 år, VD för stort företag, gift, två barn som bor hemma, en anställd boende i hushållet

\section{Jämställdhetsideal och syn på arbetsdelning}

Det finns en föreställning att hushållstjänster är bra för jämställdheten och därför har frågan om jämställdhetsideal varit viktig i undersökningen. Majoriteten av de intervjuade menar att det generellt råder brist på jämställdhet i samhället och att det finns en tydlig könsarbetsdelning $^{2} \mathrm{i}$ hemmen, något som dock inte alltid anses vara fallet $\mathrm{i}$ det egna hemmet. De flesta hävdar att kvinnor och män är något mer jämställda

2. Med "kön" ("könsarbetsdelning" och så vidare) avser jag i denna studie det socialt konstruerade könet. 
än föregående generation och menar att jämställdheten kommer öka successivt. Förändringarna anses främst ha framkallats av att kvinnor numera arbetar utanför hemmet.

Endast en av de intervjuade anser att det är naturligt att kvinnor är ensamt ansvariga för hushållsarbetet - de andra menar att arbetsfördelningen har traditionella förklaringar och är föränderlig. Att könsarbetsdelningen inte betraktas som naturgiven bekräftas av enkäten. Tio respondenter instämmer inte och tio instämmer absolut inte i påståendet "Det är naturligt att kvinnor tar hand om hemmet."

Jämställdhetsidealet är framträdande även när respondenterna diskuterar vilka förväntningar de har på sina barn. Alla hävdar att både flickor och pojkar bör hjälpa till hemma, bland annat för att undvika att konflikter uppstår när barnen blir stora och ska leva tillsammans med en partner. Vilken omfattning barnens arbetsinsats bör ha varierar dock. Flera intervjuade beklagar att barnens intressen i hemmet följer den traditionella könsarbetsdelningen. Man vill betrakta barnen som individer snarare än som "könsvarelser", vilket uttrycks i bland annat att barnen inte bör ha könstypiska beteenden - någon berättar stolt att flickan kan byta däck på bilen medan pojken är mer huslig, två intervjupersoner framhåller att pojken är ansvarskännande och ordningsam medan flickan är slarvig. Några intervjuade berättar dock om hur svårt de tycker det är att få barnen att hjälpa till: "Eftersom min man överlåter det mesta till mig när jag är hemma så gör även barnen det”, berättar Christina Castor.

Det uttrycks vissa farhågor om att barnen kan bli bortskämda av att någon annan sköter städningen i hemmet. Anki Alveteg säger:

Trots att jag inte upplever att jag är nedlåtande mot de kvinnorna [de anställda] så kan jag ju märka på min dotter att ... hon blir slarvigare, hon tycker att det kan ju hon [städhjälpen] göra. Hon [dottern] förlitar sig på att någon annan tar hand om det som behöver göras.

Andra respondenter understryker vikten av att barnen redan från början vänjer sig vid att arbeta hårt, antingen det finns huslig arbetskraft i hemmet eller inte, och Iris Isaksson säger: "Själv är jag väldigt lutherskt uppfostrad, har fått lära mig arbetsdisciplin och ansvar." Det vill hon gärna föra vidare till sina barn. Janos Jacobi uttrycker saken så här: 
Barnen bör delta i skötseln av hemmet, både av praktiska skäl, men även som en viss skolning. [...] Jag försöker som företagsledare praktisera ett sorts symboliskt ledarskap, genom mina egna handlingar vill jag få mina anställda att gå den väg jag önskar - det är likadant med barnen.

För att summera: respondenterna anser att män tvingas ta mer ansvar för hemmet när kvinnor förvärvsarbetar. Den inställningen bekräftas av uppfattningen att en ojämn fördelning av hemarbetet bara kan vara berättigad om den ena parten arbetar deltid eller inte alls. Familjen som institution har behövt anpassa sig till samhällets förändringar, det är särskilt tydligt i den familjeform jag har studerat. Tidigare var hushållsarbetet kvinnans kompetensområde. Mannen hade ett annat kompetensområde och var också längre tillbaka den som företrädde kvinnan och hushållet (Göransson 1998: I4). Idag ser det annorlunda ut: kvinnan har sitt huvudsakliga kompetensområde någon annanstans än hemma, även om hon fortfarande är huvudansvarig för hushållsarbetet. Förändringar på arbetsmarknaden har dessutom inneburit att det ställs mycket höga krav på personer som är mitt uppe i karriären.

Påverkas barnen av hur arbetsdelningen mellan föräldrarna ser ut? Ulla Björnberg och Margareta Bäck-Wiklund (1990: 87) har kommit fram till att barnen hjälper till mer ju mer jämställd arbetsfördelningen mellan föräldrarna är och tvärtom. När det däremot gäller barns attityder till jämställdhet visar en kvantitativ studie genomförd av Marie Evertsson att föräldrarnas uppdelning av hemarbetet inte har någon avgörande betydelse. Det är istället mängden hemarbete barnen utför som påverkar dem: om de hjälper till mycket hemma anser de att det är viktigt att arbetsfördelningen mellan kvinnor och män är jämn (200I: 293ff). Jag tänker mig att det skulle kunna innebära att barnen blir mindre jämställda om en anställd tar hand om hemarbetet. Den oro vissa känner över att barnen ska bli bortskämda av att någon annan sköter hemarbetet skulle i så fall vara befogad.

Samtliga intervjuade hade många funderingar om relationen mellan kvinnor och män avseende jämställdhet och arbetsdelning. Det är inte förvånande - den rådande jämställdhetsideologin påverkar människors föreställningar om kön (Björnberg \& Kollind 2003: 20). En utbredd uppfattning bland respondenterna är att könsordningen inte är naturgiven 
och att jämställdheten kan öka. Jämställdhetsidealet är också uttalat det anses önskvärt att kvinnor och män ska ha samma möjligheter. Det jämställdhetsideal som föräldrarna har för barnens vidkommande visar en syn på könen som i grunden lika - barnen ska inte bara hjälpa till hemma utan även utföra sysslor och bete sig på ett sätt som inte traditionellt förknippas med deras könstillhörighet.

\section{Hemmet som karaktärens spegel}

Alla intervjuade menade att det har stor betydelse hur det ser ut i hemmet:

Hemmet säger allt om den familj som bor där. Jag tycker det är fantastiskt roligt att komma hem till folk. Se vad de har i sin bokhylla och vad de har i sina kökslådor - jag kollar allt helt ogenerat. Jag vill undersöka vem personen är, vad läser den människan, eller så läser de inte alls, vad finns i badrumsskåpet, hur intresserade de är av mat och matlagning, var man har köpt sina möbler. Även hur städat det är kan också säga något om den som bor där (Anki Alveteg).

Det finns annat än prylar som kan signalera status, till exempel hur stor bostaden är eller var den ligger. Många vill att hemmet ska vara personligt och säga något om dem som bor där. Det verkar inte göra något om det är lite rörigt, det kan få ligga saker framme för att det säger något om familjens intressen. Men det finns olika typer av röra: det ska, enligt samtliga respondenter, vara ordentligt rent och städat. Detta är inte bara en förutsättning för att man ska kunna koppla av och trivas hemma utan även viktigt för hur man bedöms av och själv bedömer andra. Georg Göös berättar om när han kom oanmäld hem till en bekant som hade väldigt ostädat hemma, ”Den gången tänkte jag att: 'Hur kan någon bo på det här sättet?' Då fick jag en känsla att ... 'Jaså, de är på det här viset." Motsatsen gäller också: ”Är det ordning och reda så kan nog det säga att familjen har ett bra liv" (Didrik Davén).

Det får emellertid inte vara alltför perfekt; hem "där färgerna går i exakt ton och allt har sin exakta plats är [...] väldigt opersonliga" (Iris Isaksson). "Om det är för prydligt, om hemmet är som en utställningslokal istället för ett hem, då är det antagligen också något fel” (Klas Kårberg).

I kontrollintervjuerna, det vill säga de som inte köper hushållstjänster, framtonar en annan syn på hemmet. Även dessa respondenter vill att det 
ska vara städat, särskilt när de ska få gäster, men vilken ordning det är i deras eget och andras hem verkar inte ha någon överskuggande betydelse - någon säger att det är sympatiskt om det är rörigt eftersom det visar att de som bor där har viktigare saker att göra än att städa. Denna grupp kopplar inte ordningen i hemmet till familjemedlemmarnas karaktär; "Hoppas inte det är så att om man har rörigt så har man också ett rörigt liv", säger en av respondenterna. De vill inte ha det smutsigt hemma men en av de intervjuade kvinnorna säger: "Egentligen är det inte särskilt jobbigt att hålla skiten undan, [...] man behöver ju inte göra sådan stor affär av det. [...] Det kan vara mer en del av det dagliga livet."

Sammanfattningsvis tycker samtliga intervjuade att det är viktigt att det är städat och rent i bostaden, ett krav som kan vara svårt att uppfylla med tanke på att respondenterna har långa och intensiva arbetsdagar. Det verkar dock inte göra något om det är lite rörigt, tvärtom kan saker som ligger framme visa familjens personliga intressen. Ett smutsigt eller alltför välstädat hem anses tyda på att de som bor där har personliga problem. Kontrollrespondenterna anser däremot inte att det har så stor betydelse hur det ser ut i bostaden.

\section{Den faktiska fördelningen av hushållsarbetet}

När intervjupersonerna själva får beskriva hur arbetsdelningen mellan makarna i hemmet konkret går till tar några upp den så kallade lustprincipen (Björnberg \& Kollind 2003: 86f). Den innebär bland annat att var och en i första hand ska ta hand om de sysslor i hemmet de tycker är roliga. Det som nämns som lustfyllt är framför allt matlagning, inköp, dekoration och trädgårdsarbete. Främst män verkar tycka att matlagning är roligt - när kvinnorna är ansvariga för matlagningen ser de oftast själva det som en del av den specialiserade arbetsdelningen (se nedan). Med trädgårdsarbetet är det tvärtom: kvinnor som ansvarar för trädgården ser det som en hobby medan män mer talar om "uppfyllda förväntningar". Ingen av respondenterna tycker om att städa, tvätta, diska och stryka.

De undersökta familjerna faller oftast in i det etablerade könsmönstret när det gäller arbetsfördelningen. Ett flertal hävdar att det är viktigt att saker och ting fungerar rent praktiskt: "två personer kommer överens 
om hur man ska göra, en ren arbetsdelningsfråga” (Georg Göös). Det kan ske genom en specialiserad arbetsdelning, vilken för männen ofta innebär att de "betalar räkningarna och tar det elektriska, reparerar tekniska apparater, sladdar" (Janos Jacobi). Till kvinnors specialiserade arbetsuppgifter hör ofta städning, tvättning och strykning - om mannen hjälper till är det ofta på kvinnans initiativ. Till kvinnans specialisering hör också att "pyssla": vattna krukväxter, byta lakan, plocka undan och så vidare. Specialiseringen bygger alltså på de kunskaper och intressen individen tillskrivs på grundval av sin könstillhörighet, och de flesta intervjuade verkar uppfatta det som betungande och tråkigt att alltid tvingas utföra samma sysslor.

Både kontrollintervjuerna och enkäten bekräftar att denna semijämställda arbetsdelning är vanlig. Sedan 1970-talet har svenska kvinnor i snitt minskat den tid de lägger på hushållsarbete (exklusive omsorgsarbete) från omkring 32 timmar per vecka 1974 till I9 timmar 199I. Männen ökade visserligen den tid de lade på hushållsarbete under samma period, men endast från omkring två till fem timmar per vecka. Statistiska undersökningar under senare år om fördelningen av det obetalda hemarbetet visar inga större förändringar. Kvinnornas hushållsarbetstid har minskat ytterligare med över fyra timmar per vecka. Männens lönearbetstid minskade visserligen med fyra timmar per vecka, men den tiden lades inte på hushållsarbete. Skillnaderna mellan kvinnors och mäns obetalda hushållsarbete är ännu större i familjer med små barn, och när omsorgsarbetet inkluderas växer skillnaden ytterligare (Roman 2004: 7I).

I familjer som köper hushållstjänster är det enligt min studie framför allt kvinnan som ansvarar för sådant som har med den anställda att göra, särskilt när det gäller instruktion, kontroll, kontakt och stöd. Däremot är det ofta mannen som betalar ut lönen.

Sammanfattningsvis har alltså den specialiserade arbetsfördelningen i hemmet könstillhörigheten som grund, enligt de intervjuade. Den mest praktiska lösningen verkar vara att alla gör det de är bäst på. Det är ett uttryck för en komplementär syn på könen - och en direkt motsägelse till respondenternas jämställdhetsideal, vilket utmärktes av en syn på könen som lika. 


\section{Omsorgsarbete och lönearbete}

Feministiska forskare har bidragit till att synliggöra hemarbetet. De menar att det inte i första hand är ett uttryck för kärlek och omtanke utan bör betraktas som ett riktigt arbete (Delphy \& Leonard 1992: 75). Omsorgsarbete har varit ännu mer osynligt än hushållsarbete - om det överhuvudtaget är möjligt att skilja dessa två arbetskategorier från varandra (Roman 2004: 82). Majoriteten av intervjupersonerna anser att det betraktas som naturligt för kvinnor ta hand om hem och familj, hålla kontakt med släktingar och vänner, köpa presenter, skicka julkort med mera. Christina Castor uttrycker sig så här: "Omsorgsbiten är naturligt för kvinnor att ta, vi tänker på ett annat sätt, är bättre på sociala relationer, tar hand om varandra." Kvinnorna själva kan tycka att omsorgsarbetet är roligt, men ibland är det mest en plikt. När det gäller omsorgen om barnen betonas ännu starkare att det ansvaret är självklart för kvinnor att ta: "Kvinnor har lite mer omvårdande drag än män, framkallat av att de bär och föder barnen" (Eugen Eriksson).

Omsorgsansvaret kan emellertid komma i konflikt med lönearbetet. Ett påstående det råder stor enighet om i enkäten är "Kvinnor bör inte arbeta utanför hemmet" - I9 personer instämmer absolut inte (8 instämmer). Det bekräftas av intervjuerna: kvinnorna hävdar sin självklara rätt att lönearbeta och männen uttrycker sitt stöd för kvinnors lönearbete. Det anses dock att kvinnor ibland känner sig tvungna att lönearbeta och borde ges möjlighet att vara hemma några år med barnen. Att kvinnor inte är hemma kan enligt Klas Kårberg leda till "sämre kvalitet på omsorg om hem och barn. Mer stress.” Männens lönearbete blir däremot inte alls föremål för diskussion - det är norm (Ahrne \& Roman 1997: 25).

Den institutionaliserade könsarbetsdelningen kräver att man förankrar sociala klassifikationer i naturen för att undvika att klassifikationerna ska uppfattas som de sociala konstruktioner de i själva verket är (Douglas 1987). Det framställs som naturgivet att kvinnor är bättre än män på att ta hand om hem och barn, och att hon på de grunderna tillskrivs omsorgsansvaret kan innebära att hennes lönearbete betraktas som negativt för familjens bästa. Kvinnors så kallade fria val att till exempel arbeta deltid eller ta största delen av föräldraledigheten kan i själva verket vara uttryck för att hon anpassar sig efter mannens behov och underordnar 
sig honom. När jämställdhet är en dominerande ideologi uppstår lätt effekten att den patriarkala makten inte utövas öppet utan förekommer i mer förtäckt form, menar Björnberg och Kollind (2003: 77).

\section{Hushållstjänster som vardagsstrategi}

Det främsta skälet till att köpa hushållstjänster uppges vara tidsbrist, men långt ifrån alla med långa arbetsdagar anställer hemhjälp. Det kan vara vana vid och erfarenhet av huslig arbetskraft som avgör om man själv har hemhjälp; fyra av de sex intervjupersoner som har städhjälp hade huslig arbetskraft i föräldrahemmet, men endast två av de sex som har au pair. En annan viktig faktor är strukturella omständigheter som utbudet av arbetskraft och vad tjänsterna kostar, samt tillgängligheten av god offentlig barn- och äldreomsorg. Det kan i sin tur förklara varför de som har au pair inte har lika stor erfarenhet av huslig arbetskraft som de som har städhjälp - den förstnämnda gruppen är yngre i genomsnitt och samhället såg annorlunda ut när de var barn. Detta bekräftas av enkäten: av dem som hade tidigare erfarenhet av huslig arbetskraft i föräldrahemmet var majoriteten över 50 år.

Ett skäl till att köpa hushållstjänster som ofta nämns är att man slipper diskutera vem som ska utföra hushållsarbetet. De intervjuade, särskilt kvinnorna, berättar att det uppstår många tröttsamma konflikter om vem som skulle göra vad i hemmet, särskilt de sysslor som anses vara tråkigast:

Sådana diskussioner hade vi i princip dagligen tidigare, men inte nu längre, i alla fall inte i samma omfattning som innan. Och det är nog det bästa med att anlita någon: att slippa dessa ändlösa diskussioner. Det kunde verkligen tära på stämningen här hemma (Bodil Bengtsson).

Att få hjälp med städningen skänker enligt kvinnorna en "behagligare känsla” - som Harriet Hagberg uttryckte det: "Man kan känna att det faller en tyngd från hjärtat." Att kvinnor mer än män upplever köp av hushållstjänster som en konfliktlösande strategi bekräftas av enkätundersökningen. Enligt 40 procent av respondenterna, varav endast en man, kan man förhindra diskussioner om städningen genom att någon annan 
tar hand om den. Könsskillnaden bekräftas av Björnberg och AnnaKarin Kollinds studie (2003: I24ff): 35 procent av kvinnorna och 25 procent av männen uppgav att de regelbundet hade konflikter om hushållsarbete. Skillnaden var särskilt markant bland par i högre mellanskikt - 54 procent mot 28 .

Den vanligaste motiveringen till att köpa hushållstjänster är att man vill umgås mer med familjen. Flera intervjupersoner betonar vikten av att ha kvalitetstid med barnen: "Hon [au pairen] får undan rätt mycket, så när jag är ledig så kan jag vara tillsammans med mina barn helt och hållet utan störande inslag, göra grejer ihop på helgerna och så” (Filip Franzén). En au pair i familjen kan också göra det möjligt för makarna att åka på semester tillsammans utan barn. Sammanlagt 20 personer i enkäten angav som skäl till att anlita städhjälp att de ville ha mer tid till barn eller partner, vilket alltså bekräftar intervjustudiens resultat.

Ett annat vanligt skäl till att köpa hushållstjänster är att det frigör tid för mer lönearbete: ”Jag kan göra klart på jobbet mer nu än innan, behöver inte ha dåligt samvete för övertid - det är ju inte lika bråttom med att komma hem för att ta hand om städning och annat” (Bodil Bengtsson).

Några intervjupersoner nämner att det är avstressande att saker och ting i hemmet blir gjorda utan man själv behöver vara där: "När jag kommer hem från jobbet en dag när hon [städhjälpen] varit här så går jag bara runt och njuter, golven glänser och det är så skönt, jag blir verkligen glad av det” (Bodil Bengtsson). En au pair sägs vara till för barnens skull men det visar sig att skälen är fler än så: "Au pairen tar hand om barnen, hämtar på dagis. I övrigt så tar hon saker som har med barnen att göra: ger dem mat, gör i ordning deras rum. [...] Hon städar också, en gång i veckan” (Linus Lindén). Även i enkätundersökningen är en vanlig motivering att den anställda ser till att hålla hemmet i gott skick. Resultatet ligger väl i linje med de höga kraven på att bostaden ska vara välstädad och svårigheterna att hinna upprätthålla denna ordning själv.

Samtliga som har au pair anger som skäl att de vill ha barnpassning ständigt tillgänglig. För personer med väldigt långa arbetsdagar kan en au pair komplettera den kollektiva barnomsorgen (offentlig eller privat). 
Kopplingen mellan omsorgsansvaret och kvinnans lönearbete, som diskuterades ovan, blir tydlig även här:

Min fru arbetar från tidig morgon till sen kväll och det går inte att ha den minsta på dagis hela den tiden, så därför är det perfekt att ha en anställd som lämnar på morgonen vid åtta och hämtar vid tretiden på eftermiddagen (Eugen Eriksson).

Alla respondenter utom en uttrycker stort förtroende för förskoleverksamheten, men flera framhåller en au pair som en "flexibel lösning", bland annat för att hon kan vara hemma med barnen när de är sjuka istället för att föräldrarna ska behöva ta ledigt från sina arbeten. Så får konflikten mellan kvinnans ansvar för hushållsarbete och omsorg och hennes rätt till lönearbete alltså sin lösning: "Självklart ska kvinnor lönearbeta, men om det finns barn måste kanske den ena föräldern vara hemma och det blir ju ofta kvinnan. [...] Om det finns en au pair kan dock båda jobba heltid" (Filip Franzén).

Några intervjuade menar att en anledning att ha hemhjälp är att det förbättrar den anställdas situation. För Didrik Davén var det till och med det grundläggande skälet:

Att vara au pair blir ju ett sätt för dem, det enda sättet egentligen, att komma ut i världen och se andra länder. Det med au pair-systemet handlar ju om kulturmöten och det är något som jag är stor förespråkare av. Sedan att hon ser till att hålla hemmet i bra skick är ju ytterligare ett plus, det har ju vi nytta av själva, men de vi har haft har själva tyckt att det var roligt att hjälpa till så det är ju inte fråga om att man vill tvinga in dem i något. Att hjälpa till hemma hos människor som bor i andra länder är ju faktiskt ett väldigt bra sätt att lära känna den kulturen.

Kontrollgruppen avviker inte från beskrivningarna ovan gällande vare sig jämställdhetsideal, fördelning av hemarbetet, kvinnors lönearbete eller kvinnors omsorgsansvar. Skillnaden är dock att de har ideologiska betänkligheter eller skulle känna sig besvärade med en anställd i hemmet. Det enda skäl de godtar för att köpa hushållstjänster är att få hjälp med äldreomsorg om det offentliga alternativet inte skulle fungera.

Min slutsats är att strukturella förhållanden i samhället verkar ha större betydelse än tidigare erfarenheter för om denna undersöknings- 
grupp anställer huslig arbetskraft. Genom att anställa huslig arbetskraft tycks man kunna lösa konflikten mellan kvinnans ansvar för hushållsarbete och omsorg och hennes rätt till lönearbete. Som framgick i tidigare avsnitt är kvinnorna tilldelade ansvaret för den anställda. Att föreställningen om kvinnors omsorgsansvar kan utnyttjas i patriarkala syften är uppenbart, men det framgår inte varför vissa kvinnor anses kunna lämna över sitt naturgivna ansvar för barnen till en annan person, även om vederbörande vanligtvis är en kvinna. Det är främst det rutinmässiga arbetet kring barnen som den anställda ska ta hand om, men hur skiljer man det från den känslomässiga relation som säkerligen växer fram mellan barnet och den anställda? Ett sätt är att betrakta relationen som mer personlig än professionell och se au pairen som en familjemedlem. Men det blir en villkorad närhet, som upphävs om det uppstår problem - ett "falskt släktskap" (Gregson \& Lowe I994: 229f).

\section{Lämplig arbetskraft}

Städhjälpen får inte vara för dyr. Dessutom är det viktigt att den anställda är trevlig och lätt att ha att göra med samt arbetsam och professionell. Helst ska hon vara renlig och se välvårdad ut, eftersom det anses säga något om hur noggrann hon är i sitt arbete. Hon bör vara så självständig att hon inte måste instrueras varje gång hon ska städa men inte så självständig att hon snokar.

De familjer som har au pair menar att hon bör vara omvårdande och vänlig eftersom hon ska ta hand om barn. Renlighet är ett krav, liksom mognad, vilket också kopplas till barnpassningen. Hon bör dock inte vara alltför mogen - gärna ansvarsfull men fortfarande nyfiken på livet och lättlärd. Självständighet betraktas som en viktig egenskap även för au pairer, men med en lite annan innebörd än i fallet med städhjälpen: det handlar främst om att au pairen bör ha ett eget liv vid sidan av familjen. Hon ska vara lätt att ha att göra med och visa respekt för familjens privatliv och integritet samt vara anpassningsbar:

Det är viktigt att hon kan anpassa sig till oss och till våra behov, självklart måste vi anpassa oss till henne också, [...] men ärligt talat så blir nog hennes anpassning större eftersom hon bor hemma hos oss och eftersom vi har anlitat henne 
för att hjälpa oss. Det kan man ju tycka låter egoistiskt, men det är väl så som världen ser ut (Eugen Eriksson).

Ett par av de intervjuade anser att au pairen måste vara villig att arbeta hårt, andra menar att det $\mathrm{i}$ första hand är fråga om ett kulturmöte och inte en anställningsrelation. Detta kan kopplas till den tidigare diskussionen om relationen till au pairen som mer personlig än professionell.

Hur vet man då att man har fått tag på "rätt" person som städhjälp? Det vet man förstås inte förrän hon har arbetat ett tag, men för att öka sannolikheten är det viktigt med rekommendationer från bekanta. Om man svarar på en annons eller själv sätter upp en lapp på en anslagstavla är känslan av osäkerhet stor, och chansen att det ska fungera har också visat sig vara mindre. Au pair-familjerna i denna studie har använt sig av en förmedling och ibland själva kompletterat med telefonsamtal och brevväxling. Förutom att man ska dela bostad med den anställda finns ytterligare skäl till att vara noggrann vid rekryteringen: det är besvärligt att avskeda någon som har rest långt och som man inför myndigheter har förbundit sig att ta hand om ett helt år.

Samtliga intervjuade har anställt personer som är födda i andra länder, bland annat Rumänien, Somalia, Bosnien och Polen, och har antingen permanent eller temporärt uppehållstillstånd i Sverige. Respondenterna diskuterade ogärna frågan om etnicitet ${ }^{3}$, sannolikt för att de inte ville uppfattas som rasister. Det var emellertid mindre känsligt att tala om "nationaliteter", och då framkom skäl till att anställa en person född i ett annat land än Sverige. Det vanligaste argumentet när det gällde städhjälp var att den anställda behövde denna möjlighet att tjäna extra pengar. Ett annat är att invandrare är "de enda tillgängliga" för den här typen av arbeten. Kostnaden framhålls också: ”Det är klart att det spelar roll att en invandrare är billigare än en svensk, det är ju ett fruktansvärt argument men man kommer ju tillbaka till sin egen plånbok till sist” (Georg Göös). Personer från vissa delar av världen betraktas dessutom som särskilt flexibla, arbetsamma och samarbetsvilliga. Christina Castor uttrycker sig så här:

3. Med "etnicitet" avses i denna studie de socialt konstruerade kategorier som, i likhet med det sociala könet, är beroende av tid och rum. 
De [invandrarna] är mer flexibla med arbetstiden, de är mer flexibla överhuvudtaget. Svenskar är så styrda av regler, kan inte tänka sig att jobba på obekväm arbetstid till exempel. Invandrarna är mer måna om att ställa upp så flexibiliteten gäller ju inte bara arbetstiderna utan också i övrigt, [...] det blir inte så mycket diskussion som det blir med svenskar. Svenskarna har sina fackliga regler och de handlar ju mest om vad man inte ska behöva göra.

Uppfattningen är också att invandrare stannar längre i sin anställning: "Det kan vara så att svenskar snabbt får andra möjligheter och därför bara stannar kort tid, men hon vi anlitar, hon är väldigt glad över att få arbeta här hos oss, glad över att ha fått den möjligheten” (Harriet Hagberg).

Trots att svensk lag inte tillåter att man anställer någon med svenskt medborgarskap som au pair diskuterade de intervjuade fördelar med att ha anställda som är födda i ett annat land, till exempel Ukraina eller de baltiska staterna. Det vanligaste argumentet är att de är mer arbetsvilliga samt mer flexibla när det gäller arbetstiden än svenska arbetstagare.

Det där med den svenska arbetskraften är problematiskt. Svenskar har en annan uppfostran, en annan kultur. En svensk au pair skulle förmodligen ha svårt att acklimatisera sig i en familj, de skulle inte göra sitt bästa. Svenskar vill inte ha skitjobb, de är för fina. [...] Skulle överhuvudtaget inte kunna tänka mig en au pair från Tyskland eller Frankrike. Deras attityder är förmodligen väldigt lika svenskarnas (Linus Lindén).

Att den anställda får lämna fattiga förhållanden för att komma till Sverige anses bidra till en bra inställning till arbetet: "De uppfattar situationen som väldigt positiv, det skulle aldrig en svensk göra. Men hon är tacksam och då är hon kanske mer mån om att göra sitt bästa och anstränger sig för att vara flexibel” (Filip Franzén).

För dem som anlitar au pair är kontinuiteten central. Au pairer beviljas visserligen inte uppehållstillstånd i Sverige i mer än ett år, ${ }^{4}$ men ett par av de intervjuade menar att en svensk inte ens hade stannat så länge

4. Sedan flera östeuropeiska länder som förser rika västländer med arbetskraft blivit medlemmar i EU kan "arbetskraftens fria rörlighet" innebära att en familj kan anställa en barnflicka från till exempel Estland utan några tidsbegränsningar eller lönekrav. Så var dock inte fallet när denna studie genomfördes. 
utan gått vidare till studier eller ett bättre jobb. Somliga anlitar au pair för att de är intresserade av andra länder. Detta sammanfaller dock med önskemål om dels ständigt tillgänglig barnpassning, dels ett billigt alternativ till svensk arbetskraft.

I enkätundersökningen var de vanligaste skälen att anställa en person född i ett annat land att dessa anses ha större behov av denna anställning än svenskar och att bara icke-svenskar är tillgängliga för den här typen av arbete; flera respondenter har kryssat för båda. Motiveringarna står i ett avseende i motsättning till varandra: Att vilja anställa någon i hushållet och välja en invandrare eftersom det inte finns några alternativ är en sak. Att hävda att man har gjorde det för att invandrare har störst behov av den här typen av anställningar kan då möjligen göra att relationen blir acceptabel eftersom båda parter tjänar på den.

Andra skäl som angetts i enkäten är att invandrare uppfattas som mer arbets- och samarbetsvilliga än svenskar, skvallrar mindre, är mer flexibla när det gäller arbetstiden, tar mindre betalt (ungefär 35 procent svarade att den höga kostnaden är en av de största nackdelarna med att ha huslig arbetskraft) och stannar längre i sin anställning. Resultatet är alltså väldigt likt det som framkommit i intervjuerna.

Föredrar de flesta att anställa svart istället för vitt enbart av ekonomiska skäl? Det framkommer att man upplever att arbetet blir bättre utfört samt att kontinuiteten och flexibiliteten blir större vid svart anställning. Det kan förklaras med att man själv är den som rekryterar den anställda, ofta någon som har svårt att få in en fot på arbetsmarknaden som är tacksam över att få denna möjlighet och således stannar länge på sin plats. Bristen på kontroll över vem som kommer att vistas $\mathrm{i}$ bostaden, den höga personalomsättningen samt formella regler och lagar som ska följas är andra faktorer som gör att många drar sig för att anställa vitt. Likheten med argumenten för att anställa en person som är född i ett land med sämre livsvillkor än Sverige är slående.

Respondenterna fick ta ställning till vilka rättigheter de ansåg att de anställda skulle ha utifrån en lista över de vanligaste arbetsrättsliga reglerna. De som har städhjälp menar att rättigheterna bör gälla generellt på arbetsmarknaden men inte är tillämpliga i just deras fall, för att de har svart arbetskraft eller för att det endast är fråga om ett litet antal arbets- 
timmar. De som har au pair tycker inte heller att rättigheterna är tillämpliga eftersom au pairer formellt sett inte är anställda i vanlig mening.

En förklaring till att det är vanligt att arbetskraften förkroppsligas inom hushållssektorn kan vara att den anställdas övergripande uppgift, enligt Bridget Anderson (2000: 2), är att reproducera den kvinnliga arbetsgivarens status (mellanskikt, icke-arbetare, ren) i kontrast till sig själv (arbetare, degraderad, smutsig). Det gör maktrelationen mellan dem ojämn, vilket kan förklara varför det idag framför allt är personer med annan klassmässig och etnisk tillhörighet än arbetsgivaren som anlitas.

\section{Myntets baksida}

Respondenterna är glada över att få hjälp med hemarbetet men berättar om negativa aspekter: oron över försvunna nycklar och rädslan för att anställda ska hitta känsliga uppgifter och använda dem i "ondskefullt syfte". Ingen av dem som har städhjälp säger sig ha blivit bestulen men rädslan finns ändå där, och den förstärks av att det är fråga om svart anställning så att en polisanmälan inte är ett alternativ om något verkligen skulle hända. Att inte känna sig bekväm hemma när städhjälpen är där är en annan negativ aspekt, särskilt för den som arbetar hemifrån: "Min frihet blir beskuren, då när de städar då är det deras mark på nåt sätt. [...] Vart ska jag ta vägen, ska jag gå ner i källaren då eller?” (Georg Göös). Känslan av olust kan också ha att göra med den moraliska aspekt två intervjuade nämner, att det inte är socialt accepterat att ha hjälp i hemmet. Det uppfattas även som besvärligt att det helst ska plockas undan innan städhjälpen ska komma: "Dagen innan hon kommer så måste vi plocka upp allting [...] Det är faktiskt jobbigt att lägga ner så mycket tid på det, en hel kväll i veckan brukar det bli” (Bodil Bengtsson).

Christina Castor vill vara hemma när städhjälpen kommer för att de ska göra arbetet tillsammans. Hon trivs inte särskilt bra med det men eftersom rädslan för att bli bestulen är större står hon ut. Det leder dock till ännu en negativ aspekt - att behöva hantera den anställdas personliga problem:

Eftersom vi tar städningen ihop så blir det ju så att vi pratar en del och då tar hon ofta upp saker, [...] sådana besvärligheter som många invandrare utsätts för eftersom de inte kan språket så bra eller för att de inte vet hur saker och ting 
fungerar. [...] Man vill ju gärna hjälpa till, men det tar ju rätt mycket tid, skulle vara rätt skönt att slippa det egentligen.

En annan intervjuad kvinna har liknande problem: den anställda berättar mycket om sig själv vilket tar tid och framkallar stress. Ingen av de intervjuade männen tar upp denna fråga, vilket kan bero på att det främst är kvinnorna som har ansvar för och kontakt med de anställda eller på att de anställda har lättare att anförtro sig åt en kvinna.

Endast 16 respondenter i enkäten svarade på frågan om negativa aspekter av att köpa hushållstjänster. Övriga antingen uppgav att de var så nöjda med hjälpen att de inte såg några negativa aspekter eller hoppade över frågan utan kommentar. Att kostnaden är den negativa aspekt som flest nämner är inte förvånande eftersom den här uppgår till too kronor i timmen - till skillnad från de 60-70 kronor i timmen de intervjuade betalar i svart lön för städhjälpen. Flera studier visar att hushållstjänster är extremt priskänsliga och att det inte handlar om betalningsförmåga utan om betalningsvilja (se SOU 1994:43: kap 4; SOU 1997:I7: 353f).

Att ha au pair kan vara förenat med mer påtagliga besvär jämfört med att ha städhjälp några timmar i veckan. De intervjuade betonar att de är måna om att au pairen ska trivas och känna sig som en i familjen. Flera berättar dock att de känner sig besvärade när de och au pairen är hemma samtidigt, varför det är nödvändigt sätta upp gränser för att värna familjens privata liv. En negativ aspekt av att ha en anställd boende hos sig är enligt de intervjuade att hon har en benägenhet att röra sig i hemmet som om det vore hennes eget. För att förebygga detta bör au pairen ha eget rum och hon ska helst vara ute ofta och träffa andra än familjen, ”i alla fall så länge det inte inkräktar på arbetet hon ska göra hos oss” (Linus Lindén).

Precis som de som har städhjälp anser värdfamiljerna att de alltför mycket måste hantera au pairens personliga problem:

Vi är ju väldigt måna om att au pairerna ska ha det bra här i Sverige och hemma hos oss, vi vill ju gärna hjälpa dem - men ibland kan det bli lite för mycket, särskilt när de nyligen har kommit så kan ju språkbristerna ställa till stora problem. Vi får lägga ner mycket tid på att hjälpa dem komma till rätta och det kan bli ganska tröttsamt ibland (Didrik Davén). 
Stöldrisken nämner samtliga som en nackdel. Något annat som inte ses med blida ögon är att au pairer som arbetar i samma område ibland träffas och då sägs skvallra om "sina" familjer. En annan negativ erfarenhet som nämns är att en au pair var ute och "raggade karlar" på nätterna och sov länge på morgnarna.

\section{Jämställdhet och hushållstjänster}

Det finns tecken på att den traditionella könsarbetsdelningen i svenska familjer delvis kan ha ersatts av ett förhandlingssystem. Studien visar att det är vanligt att det uppstår konflikter om vem som ska ansvara för hushållsarbete och barn, särskilt om det inkräktar på lönearbetet. Det talar för att arbetsdelningen i hushållet inte längre självklart bygger på könslinjer - i så fall skulle knappast några konflikter uppstå. Den tydliga rollfördelning som fanns i kärnfamiljen har, enligt Åsa Lundqvist och Christine Roman (2003: I3ff), ersatts av "den förhandlande familjen” där individualismen är institutionaliserad.

Allt fler kvinnor satsar på yrkeskarriär och det kan påverka hur de ser på hushållsarbete och omsorgsansvar. Björnberg och Kollind (2003: I24ff) visar att ju mer kvinnor lönearbetar och ju högre position de har i arbetslivet, desto vanligare är det att de upplever konflikter i hemmet. Detta samband är inte lika starkt för män. Livsformsanalysen bekräftar detta: karriärlivsformen skiljer inte mellan arbete och fritid utan mellan engagemang och rutin. Den som har en hög och ansvarsfull position i arbetslivet är mindre villig att utföra enformigt rutinarbete, till exempel hushållsarbete, än den som har ett okvalificerat lönearbete (Jakobsen 1999: I79f). Könsarbetsdelningen verkar emellertid inte ha genomgått någon dramatisk förändring generellt sett, kanske för att maktasymmetrin mellan kvinnor och män leder till att de går in i förhandlingen på olika villkor. Det bekräftas av denna studie: kvinnan utför fortfarande betydligt mer hushållsarbete än mannen, kvinnan tillskrivs ett naturligt omsorgskännande, ordningen $\mathrm{i}$ hemmet anses säga mer om kvinnan än om mannen och kvinnans lönearbete är inte lika självklart som mannens.

Det är framför allt kvinnans obetalda arbete som den husligt anställda ska ersätta. Att köpa hushållstjänster kan alltså vara en strategi för att 
lösa de konflikter som uppstår till följd av att hemarbetet är föremål för förhandlingar, men det finns inget i undersökningen som talar för att familjer som köper hushållstjänster har andra jämställdhetsideal eller -praktiker än familjer generellt. Även om köpet av hushållstjänster avlastar kvinnorna tillkommer ansvaret för att instruera och kontrollera den anställda.

Familjerna i min studie har en semijämställd arbetsfördelning, vilket kort innebär en specialisering efter könslinjer. Min studie bekräftar vad Margareta Bäck-Wiklund och Birgitta Bergsten (I997: I4) fastslår: de flesta i Sverige ställer sig bakom jämställdhetsidealet men få organiserar sitt liv efter det. När en utomstående kvinna tar över hushållsarbetet istället för att fördelningen mellan kvinnan och mannen utjämnas upprätthålls den rådande könsarbetsdelningen. Avlastningen ger emellertid karriärkvinnor möjlighet att konkurrera med män i arbetslivet på lite mer lika villkor.

\section{Ett verkligt problem}

Är svårigheterna med att hinna med hemarbetet ett verkligt eller bara ett upplevt problem? Långa intensiva arbetsdagar i kombination med småbarn gör det svårt att hinna med hemarbetet. Anderson (2000: 14) hävdar dock att detta arbete ofta kan handla om att upprätthålla livsstil och status. Kraven på hur det ska se ut i bostaden skulle enligt detta resonemang vara ett upplevt, livsformsspecifikt problem, liksom behovet av kvalitetstid och ointresset för att själv upprätthålla den önskvärda ordningen. Att köpa hushållstjänster är således både en strategi för att klara av vardagen och ett sätt för mellanskikten att upprätthålla könsarbetsdelning och specifika livsmönster.

\section{Maximering av familjens betydelse}

Det har hävdats att ökad individualism har bidragit till att relationerna i familjen alltmer påminner om arbetslivets hårda värld (Roman 2004: 48). Därför finns intressen som vill öka familjens betydelse i samhället och för det ändamålet används community-begreppet, som har sitt ursprung i Gemeinschaft-begreppet och står för den gemenskap och när- 
het som anses komma till uttryck i familjen, släkten och vänkretsen (Björnberg \& Bäck-Wiklund 1990: 35) och är centralt i diskussionen om familjens återtagande av sin viktiga funktion i samhället. Enligt vissa familjesociologiska teorier är familjen på väg att bli viktigare därför att den erbjuder en tillflykt i vårt opersonliga och osäkra överflödssamhälle (Roman 2004: 137). Frågan är då om köp av hushållstjänster kan vara en strategi för att återskapa hemmet som en plats för gemenskap och närhet. Det budskapet finns i alla fall i marknadsföringen av hushållstjänster; genom att visa upp en tecknad bild av ett par före och efter anlitande av städhjälp och barnpassning framställer ett hushållstjänsteföretag hemmet som en plats för vila och kärlek (Platzer 2003: 26I).

I denna studie kan köp av hushållstjänster framstå som ett sätt att maximera familjens funktion genom att öka tillgången på kvalitetstid. Enligt Brembeck (1997: 83) är det karakteristiskt för de övre mellanskikten att engagera familjemedlemmarna i gemensamma aktiviteter och man har också ett utpräglat aktivt fritidsliv. Det framstår dock inte som självklart att den frigjorda tiden ägnas åt rekreation - i själva verket kan mer tid än tidigare läggas på lönearbete.

En förutsättning för att betrakta hemmet som en motvikt till det individualiserade arbetslivet är dock att man kan skilja familjen som institution från samhället i övrigt. Uppfattningen att samhället är uppdelat i en offentlig och en privat sfär uppstod, enligt en riktning inom familjesociologin, på grund av att familjen vid övergången till industrisamhället blev alltmer beroende av andra institutioner. Detta var en konsekvens av en ökande differentiering - sociala institutioner blev mer specialiserade samtidigt som de förlorade tidigare funktioner. Detta hade, enligt vissa, att göra med att många av familjens funktioner överfördes till andra sociala institutioner samtidigt som dess känslomässiga funktion ökade i betydelse (Roman 2004: 28). Christine Delphy och Diana Leonard (1992: kap I) hävdar däremot att hemmet är en viktig socioekonomisk institution och att familjen inte kan reduceras till en reproduktiv roll. Inte heller Christopher Lasch (1995: 35) anser att familjen är en isolerad enhet. Relationerna i familjen har påverkats av det omgivande samhället, vilket bekräftar att familjen är en del av samhället. Detta har, menar Lasch (ibid: I49), gjort det svårare för familjen att erbjuda individen 
moralisk och social fostran. Inom feministisk forskning har man däremot visat att hemmet inte har utmärkt sig för att vara en plats för vila och harmoni, i alla fall inte för de kvinnor som genom sitt obetalda arbete sett till att andra familjemedlemmar har kunnat koppla av och rekreera sig (Roman 2004: 47).

\section{Kontroll och risk}

De som ingår i studien nämner många negativa aspekter med att ha anställda hemma: de kan stjäla, skvallra, uppta ens tid med sina personliga problem och göra att man kan känna sig besvärad hemma. Trots det väljer alltså många att anlita huslig arbetskraft. Mycket tyder på att arrangemanget bygger på att de anställda har vissa egenskaper och sociala positioner som gör dem lämpliga för den här typen av arbete. Dessa egenskaper och positioner återfinns framför allt hos personer som kommer från fattiga förhållanden och befinner sig utanför den reguljära arbetsmarknaden.

I tidigare studier (Platzer 2002, Platzer 2003) finns resonemang om att det inte enbart är ens betalningsförmåga eller -vilja som avgör om man köper hushållstjänster, utan de allra flesta familjer vill att köpet ska vara oreglerat och informellt. Låga kostnader är visserligen viktigt, men också att ha kontroll över arbetskraften. För att komma fram till vad som karakteriserar hushållstjänstearbetet räcker det sannolikt inte med att titta på vilka de konkreta arbetsuppgifterna är och i vilka fysiska miljöer de utförs, det är också viktigt att studera det sociala sammanhanget. Hushållstjänstearbete utförs visserligen ibland som rent lönearbete och i standardiserad form, men den delen av hushållstjänstebranschen är liten. Det mesta tyder på att svarta anställningar dominerar, och det finns andra alternativ som inte omfattas av arbetsrätt, socialförsäkringar med mera, till exempel au pairsystemet. Många föredar sådana informella lösningar (Platzer 2002: 19). Man är beredd att ta vissa risker för att få kontroll. 


\section{Referenser}

Ahrne, Göran \& Roman, Christine (1997) Hemmet, barnen och makten. Förhandlingar om arbete och pengar i familjen, SOU 1997:139, Stockholm: Fritzes.

Anderson, Bridget (2000) Doing the Dirty Work? The Global Politics of Domestic Labour, London: Zed Books.

Björnberg, Ulla \& Bäck-Wiklund, Margareta (1990) Vardagslivets organisering i familj och närsamhälle, Göteborg: Daidalos.

Björnberg, Ulla \& Kollind, Anna-Karin (2003) Att leva själv tillsammans, Malmö: Liber.

Brembeck, Helene (1997) Efter Spock. Uppfostringsmönster idag, Göteborg: Etnologiska föreningen i Västsverige.

Bäck-Wiklund, Margareta \& Bergsten, Birgitta (1997) Det moderna föräldraskapet. En studie av familj och kön i förändring, Stockholm: Natur och Kultur.

Delphy, Christine \& Leonard, Diana (1992) Familiar Exploitation. A New Analysis of Marriage in Contemporary Western Societies, Cambridge: Polity Press.

Douglas, Mary (1987) How Institutions Think, London: Routledge \& Kegan Paul.

Evertsson, Marie (200I) "Barns hushållsarbete och könsroller", i Barns och ungdomars välfärd, Kommittén Välfärdsbokslut, SOU 200I:55, Stockholm: Fritzes.

Gregson, Nicky \& Lowe, Michelle (1994) Servicing the Middle Classes. Class, Gender and Waged Domestic Labour in Contemporary Britain, London: Routledge.

Göransson, Anita (1998) "Mening, makt och materialitet”, i Häften för kritiska studier, nr 4.

Jakobsen, Liselotte (1999) Livsform, kön och risk. En utveckling och tillämpning av realistisk livsformsanalys, Lund: Arkiv förlag.

Lasch, Christopher (1995) Haven in a Heartless World. The Family Besieged, New York: W.W. Norton \& Company.

Lundqvist, Åsa \& Roman, Christine (2003) "Önska, välja och vilja. Om beslutet att skaffa barn", i Sociologisk forskning, nr I.

Platzer, Ellinor (2002) "Kulturellt utbyte eller billig arbetskraft? Au pair i Sverige", i Sociologisk forskning, nr 3-4.

Platzer, Ellinor (2003) "Genuskontrakt och social differentiering. Om karriärfamiljers efterfrågan på hushållstjänster", i Mulinari, Diana; Sandell, Kerstin \& Schömer, Eva (red.) Mer än bara kvinnor och män. Feministiska perspektiv på genus, Lund: Studentlitteratur.

Roman, Christine (2004) Familjen i det moderna. Sociologiska sanningar och feministisk kritik, Malmö: Liber.

SOU 1994:43 Uppskattad sysselsättning. Om skatternas betydelse för privata tjänstesektorn, betänkande av Tjänsteutredningen, Stockholm: Fritzes.

SOU 1997:I7 Skatter, tjänster och sysselsättning, betänkande av Tjänstebeskattningsutredningen, Stockholm: Fritzes. 


\section{Ellinor Platzer \\ Från follkhem \\ till karriärhushåll}

Den nya husliga arbetsdelningen
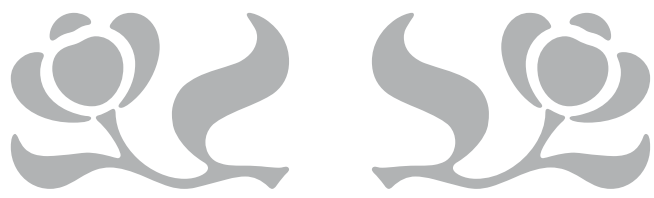

Arkiv förlag 2007, mjukband, 144 sidor

\section{Rebecca Selberg}

Femininity at Work

\section{$\bullet$ \\ Gender, Labour \\ and Changing \\ Relations of Power \\ in a Swedish Hospital}

Arkiv förlag 2012, mjukband, 364 sidor

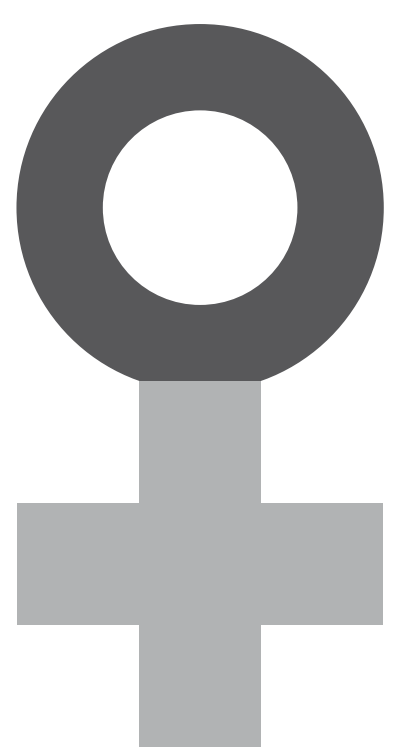

»Läs mer om böckerna på www.arkiv.nu« 